\title{
APPLICATION OF IN SITU HYBRIDIZATION FOR THE DETECTION OF VIRUS GENOMES IN TISSUE
}

\author{
Tsuyoshi TAKASU ${ }^{1,2}$, Yasushi FURUTA ${ }^{1,2}$, Seigo SUZUKI ${ }^{1,2}$, \\ Yoshiniko OBARA ${ }^{1}$ and KazUo NAGASHIMA ${ }^{1 *}$ \\ Departments of Pathology ${ }^{1}$ and Otolaryngology ${ }^{2}$, Hokkaido University School \\ of Medicine, North 15, West 7, Kita-ku, Sapporo 060
}

\begin{abstract}
We applied in situ hybridization (ISH) using RNA probes which hybridize with infected-cell protein number zero (ICPO) mRNA or latency-associated transcripts (LAT) to detect herpes simplex virus type 1 (HSV-1) in both latent and productive infections. In the productive stage, in which the production of viral particles can be shown by immunohistochemistry and electron microscopy, we demonstrated the presence of ICPO mRNA and LAT, which indicates that LAT may also be transcribed in productive infection. In latent infection of the trigeminal and geniculate ganglia, where HSV antigen cannot be detected by immunohistochemistry, we detected positive hybridization signals using ISH with ICPO sense RNA probe, which is complementary to LAT. Positive signals were not detected with ICP0 antisense probe. We could not demonstrate HSV latency in the spiral ganglia using ISH, although the HSV genomes were amplified by using the polymerase chain reaction method. These results demonstrate that ISH is a convenient, but limited, technique for the detection of latent HSV.
\end{abstract}

The detection of viruses in tissue requires a knowledge of their characteristics and behavior. The viral life cycle consists of a fairly limited number of essential steps. These steps include: bonding to a susceptible cell; gaining entry to either the cytoplasm or the nucleus; successfully shedding the viral coat; directing the synthesis of templates for the replication of the genome and the formation of mRNA; synthesizing progeny genomes, mRNAs, and the proteins that comprise the viral particles; assembling the virions; and, if the infection is productive, successfully releasing the progeny particles from the host cell. Electron microscopy can detect the particles after the step of virion assembly, and immunohistochemical analyses can indicate the presence of the virus after protein synthesis has occured. In productive virus infection, however, the use of in situ hybridization (ISH) allows detection at the point of genome replication.

Latent infections may occur with viruses such as herpes simplex and varicella-zoster. Latent infection is a persistent infection that occurs as an acute primary infection, disappears and remains dormant for a long

\footnotetext{
* To whom correspondence should be addressed.
}

This work was supported by special coordination funds for promoting science and technology, The Science and Technology Agency, Japan. time, and then reappears during recurrence of disease (1). While ultrastructural and immunohistochemical analyses can detect viruses in their acute and recurrent phases, they cannot detect those in the dormant or latent stage. However, recent molecular studies have revealed that viruses in the latent stage do produce characteristic signals (11), and that these signals can be detected at the cellular level by the ISH method (2).

We used the herpes simplex virus (HSV), in both acute and latent stages of infection, to show the advantages of the ISH method for the detection of viral infection.

\section{MATERIALS AND METHODS}

\section{Tissue specimens:}

Trigeminal ganglia, geniculate ganglia, and modioli including spiral ganglia were obtained from 10 adult autopsy cases at 1 to $13 \mathrm{hr}$ after death. None of the patients had symptoms of HSV infection at the time of the autopsy. One half of each material was immediately stored at $-70^{\circ} \mathrm{C}$, and DNAs were extracted from the subjects for analysis using the polymerase chain reaction (PCR) method. The other half was immersed in $10 \%$ buffered formalin for 1 to 3 days and embedded in paraffin. Modioli and a trigeminal ganglion from one case were decalcified in $10 \%$ 
ethylene diamine tetraacetic acid (EDTA) for 3 to 7 days prior to embedding. We used DNA extracted from HSV-1 strain K192 as a positive control for the PCR. Ganglia from a newborn baby were used as a negative control. Brain tissue from a patient who died of acute HSV encephalitis was used as a specimen for the productive phase of HSV infection. The clinicopathologic details of this case have been reported elsewhere (5).

Polymerase chain reaction:

We used a pair of HSV TK primers (TK 1: $5^{\prime}$ ATACCGACGATATGGGACGT-3', TK 2: 5'TTATTGCGGTCATAGGGGGG-3') $(6,7)$, which are specific for a portion of the HSV-1 thymidine kinase gene, to detect the HSV-1 by PCR (12). For each sample, $1 \mu \mathrm{g}$ of tissue DNA or $1 \mathrm{ng}$ of viral DNA was amplified 30 times on a DNA thermal cycler (Thermal Cyclic Reactor Model TC-100, Hoei Science, Japan). One PCR cycle consisted of denaturation at $93^{\circ} \mathrm{C}$ for $2 \mathrm{~min}$, annealing at $50^{\circ} \mathrm{C}$ for $2 \mathrm{~min}$, and primer extension at $72^{\circ} \mathrm{C}$ for $3 \mathrm{~min}$. One fourth of the PCR products were loaded on agarose gels composed of $1 \%$ Seakem $/ 3 \%$ NuSieve (FMC BioProducts, Chicago, IL, USA) and were transferred to nylon membranes (Hybond $\mathrm{N}+$, Amersham International plc, Buckinghamshire, UK). The amplified HSV-1 DNA was detected by Southern blot hybridization with a ${ }^{32} \mathrm{P}$-labeled probe generated by additional PCR
(12).

In situ hybridization:

The HSV-1 DNA probe consisted of a $2.6 \mathrm{~kb}$ SalI/BamHI DNA fragment derived from the BamHI$B$ restriction fragment of the HSV-1 strain (8). This DNA fragment contains the infected-cell protein number zero (ICP0) gene and the latency-associated transcript (LAT) gene (Fig. 1). The fragment was labeled with $\left[{ }^{35} \mathrm{~S}\right] \mathrm{dCTP}$ (Amersham) using the random primer method. The $2.6 \mathrm{~kb}$ Sall/BamHI fragment was cloned into pSPT18, which contains SP6 and T7 RNA polymerase promoters. The RNA probes were synthesized in opposite directions to that of ICP0 mRNA (ICP0 antisense probe) and LAT (ICP0 sense probe) (3). These RNA probes were labeled with a digoxigenin-uridine-triphosphate substrate.

In situ hybridization was performed as described previously (9). Briefly, thin sections $(5 \mu \mathrm{m})$ of the paraffin-embedded tissues were mounted on slides coated with 3-aminopropyl-triethoxysilane. The tissues were deparaffinized and rehydrated by sequential immersion in xylene and graded ethanols. The sections were treated in $0.2 \mathrm{~N} \mathrm{HCl}$ for $20 \mathrm{~min}$ and $100 \mu \mathrm{g} / \mathrm{ml}$ proteinase $\mathrm{K}$ (Boehringer Mannheim, Mannheim, Germany) at $37^{\circ} \mathrm{C}$ for $15 \mathrm{~min}$. After post-fixation with $4 \%$ paraformaldehyde in phosphate-buffered saline (PBS) for $5 \mathrm{~min}$, the excess aldehydes were neutralized twice with $0.2 \%$ glycine in PBS for
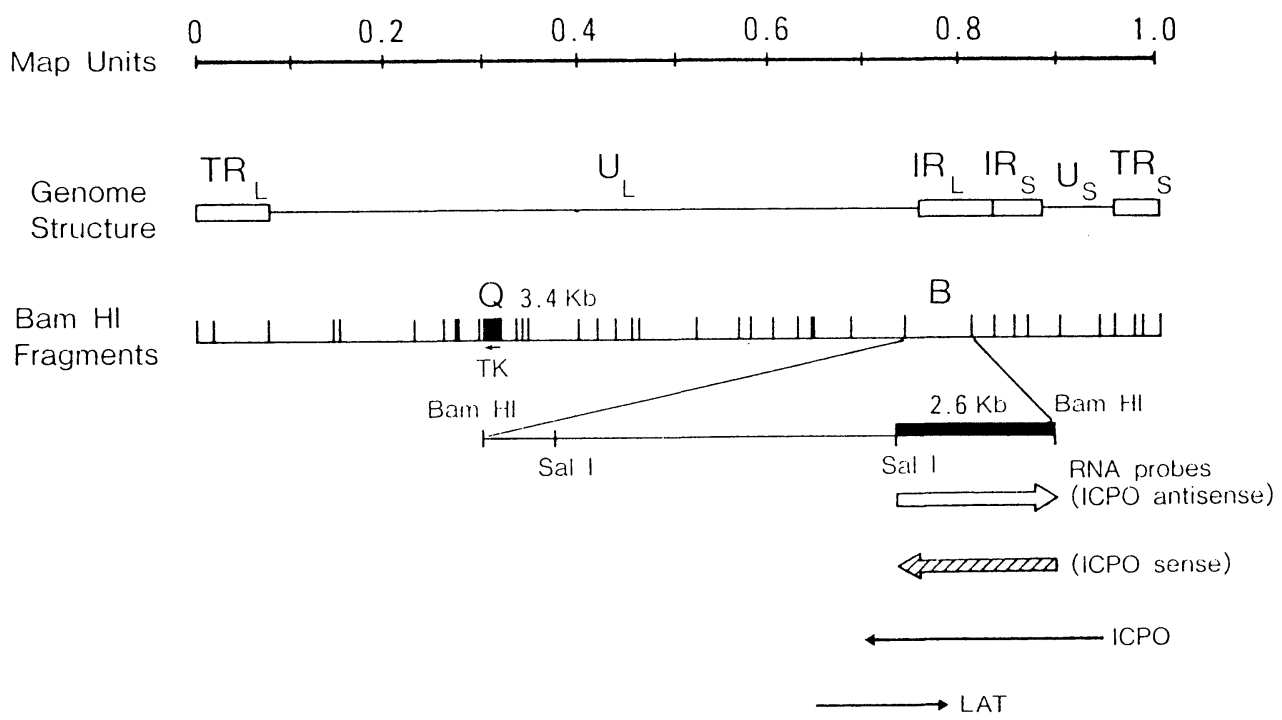

FIG. 1. Genomic structure of herpes simplex virus type 1 (HSV-1) and location of probes used in this study. The 3.4-kb BamHI$Q$ restriction fragment contains the region which encodes the thymidine kinase (TK) gene. The 2.6-kb Sall/BamHI DNA fragment derived from the BamHI-B restriction fragment contains the infected-cell protein number zero (ICP0) gene and the latencyassociated transcript (LAT) gene. The RNA probes were synthesized in directions opposite to those of ICP0 (ICP0 antisense probe) and LAT (ICP0 sense probe). 
$15 \mathrm{~min}$, and the sections were washed in PBS.

For the DNA probes, hybridization was performed at $42^{\circ} \mathrm{C}$ for $18 \mathrm{hr}$ in a mixture of $50 \%$ deionized formamide, $5 \times$ SSPE $(1 \times$ SSPE: $0.18 \mathrm{M} \mathrm{NaCl}, 10 \mathrm{mM}$ $\mathrm{NaH}_{2} \mathrm{PO}_{4}, 1$ mM EDTA, pH 7.4), $5 \times$ Denhardt's solution, $0.1 \%$ sodium dodecyl sulfate (SDS), $100 \mu \mathrm{g} /$ $\mathrm{ml}$ denatured salmon sperm DNA, 10\% dextran sulfate, and $0.2 \mathrm{ng} / \mu \mathrm{l}{ }^{35} \mathrm{~S}$-labeled probe. The slides were washed in $50 \%$ formamide, $2 \times \mathrm{SSC}(1 \times \mathrm{SSC}$ : $0.15 \mathrm{M} \mathrm{NaCl}, 15 \mathrm{mM}$ sodium citrate) at $55^{\circ} \mathrm{C}$ and then dipped in Konica NR-M2 emulsion for autoradiography. The slides were exposed for 7 days and were then developed and counterstained with hematoxylin.

For the RNA probes, hybridization was performed at $50^{\circ} \mathrm{C}$ for $18 \mathrm{hr}$ in $50 \%$ deionized formamide, $600 \mathrm{mM} \mathrm{NaCl}, 10 \mathrm{mM}$ Tris (pH 7.6), $1 \mathrm{mM}$ EDTA, $10 \mathrm{mM}$ dithiothreitol, $1 \times$ Denhardt's solution, $0.25 \%$ SDS, $200 \mu \mathrm{g} / \mathrm{ml}$ Escherichia coli $t R N A$, and $5 \mathrm{ng} / \mu \mathrm{l}$ of digoxigenin-labeled probe. The slides were washed in $50 \%$ formamide, $2 \times \mathrm{SSC}$ at $60^{\circ} \mathrm{C}$, immersed in $0.5 \%$ blocking reagent solution (Boehringer Mannheim) for $30 \mathrm{~min}$, and were then washed in DIG buffer $1(0.1 \mathrm{M}$ Tris-HCl, $0.15 \mathrm{M} \mathrm{NaCl}, \mathrm{pH} 7.5)$. The slides were then incubated for $30 \mathrm{~min}$ with alkaline phosphataseconjugated anti-digoxigenin antibody and diluted $1: 5000$ in DIG buffer 1 . The slides were then washed twice with DIG buffer 1 for $15 \mathrm{~min}$ and were rinsed in DIG buffer $3(0.1 \mathrm{M}$ Tris-HCl, $0.1 \mathrm{M} \mathrm{NaCl}, 0.05 \mathrm{M}$ $\mathrm{MgCl}_{2}$, pH 9.5) for $2 \mathrm{~min}$. The color reaction was performed with nitroblue tetrazolium salt and 5-bromo-4- chloro-3-indolyl phosphate solution.

\section{RESULTS}

In acute productive infection with herpes simplex virus, both virus proteins and nucleic acids are synthesized (5). The RNA probes hybridized with ICP0 mRNA or LAT were applied to a case of acute HSV encephalitis. The neurons which contained large amounts of viral protein or virus particles were also hybridized with the ICP0 antisense probe and revealed that ICP0 mRNA was transcribed and viral DNA was replicated in productive infection (Fig. 2a). However, positive hybridization signals were also detected with the ICP0 sense probe (Fig. 2b). While the LAT gene has been considered to be associated with viral latency, these results confirm previous findings with mice (10) that LAT is also transcribed in productive infection.

Using a radiolabeled, ISH DNA probe, we confirmed the presence of HSV-1 LAT in human trigeminal ganglia (Fig. 3a). HSV-positive neurons were found in 6 of 10 samples. Positive signals were detected only in the nuclei of neurons, but not in those of non-neuronal cells, such as satellite cells, Schwann cells, fibroblasts, and endothelial cells of the ganglia.

Human sensory ganglia of the facial nerve and vestibulocochlear system have not been examined for HSV viral latency, although the implications of possible HSV reactivation have been postulated as the cause of idiopathic facial nerve palsy (Bell's palsy)

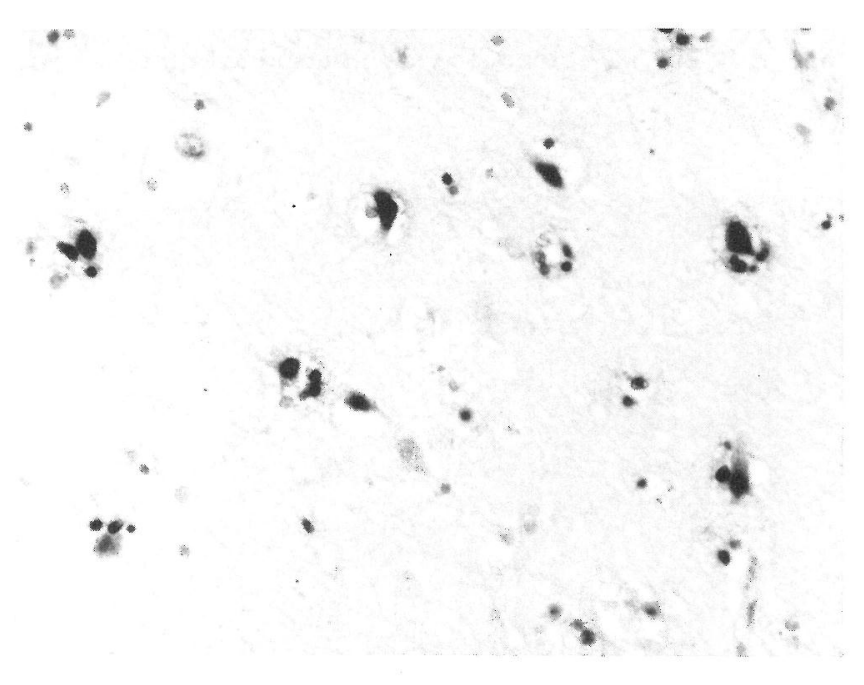

a

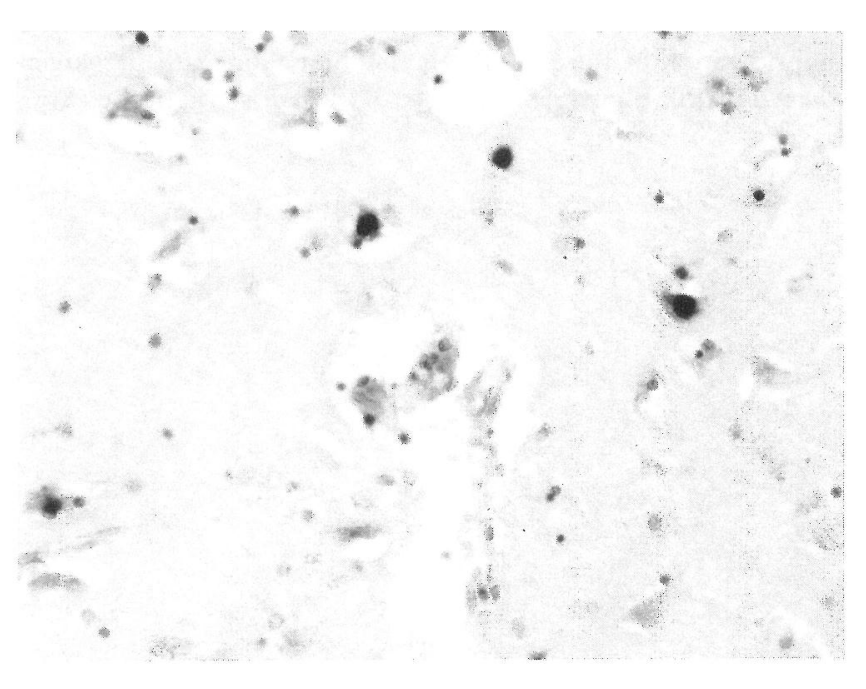

b

FIGS. 2a, b. Brain tissue specimen from a patient with HSV-induced encephalitis. Positive signals were seen in the parenchyma of the affected neurons by in situ hybridization, both with the ICP0 sense probe (Fig. 2a) and with the ICP0 antisense probe (Fig. $2 \mathrm{~b})$. 
(13). We examined the ganglia using non-radioactive RNA probes (ICP0 sense probe) (Fig. 1), which were complementary to LAT, and which hybridized with the nuclei of neurons from geniculate ganglia (Fig. 3b). However, ICP0 antisense probe (Fig. 1), which was complementary to ICP0, did not hybridize with any cells (Fig. 3c). In 7 of our 10 samples, the HSV signals were detected in the geniculate ganglia at a rate

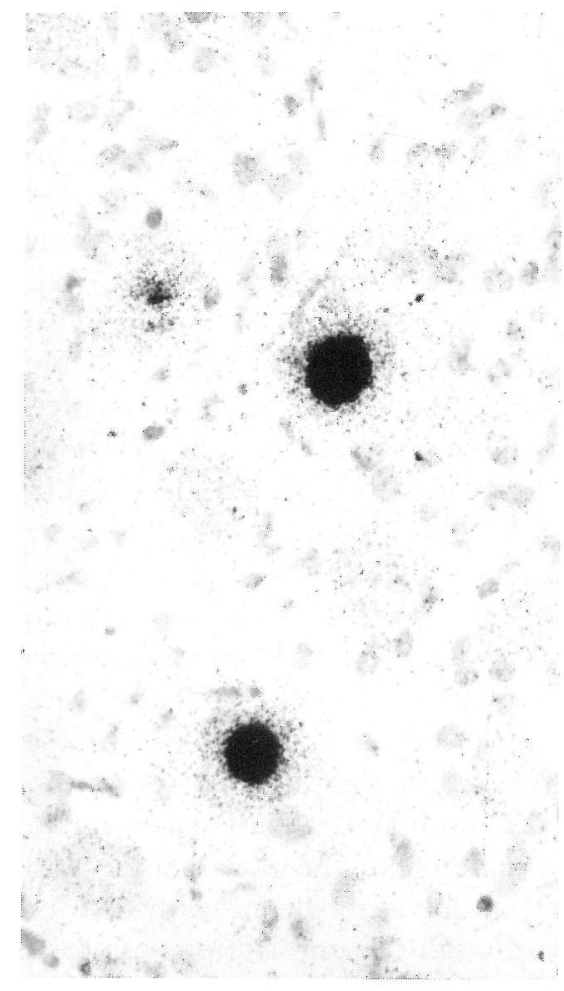

a

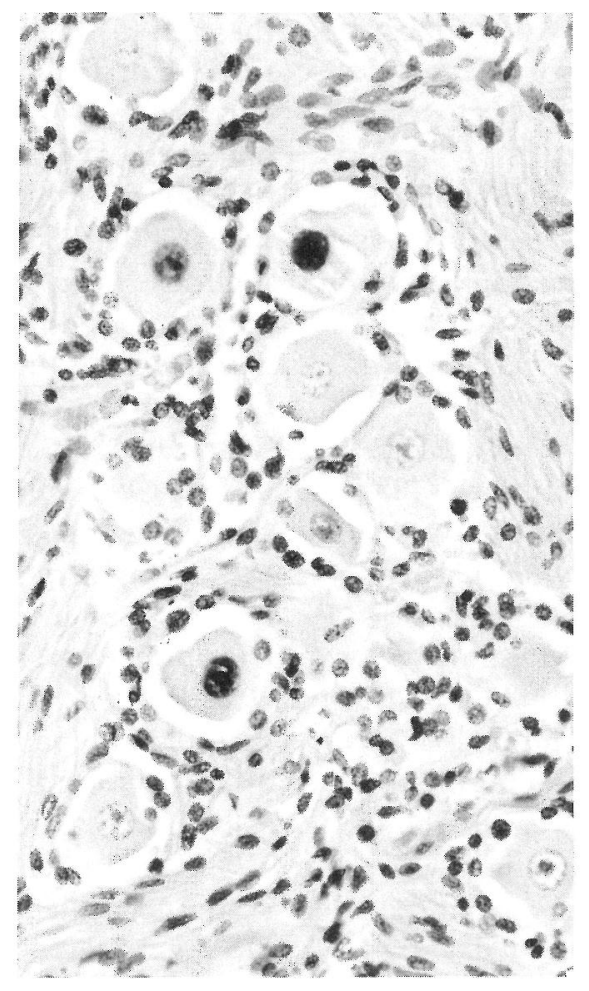

b

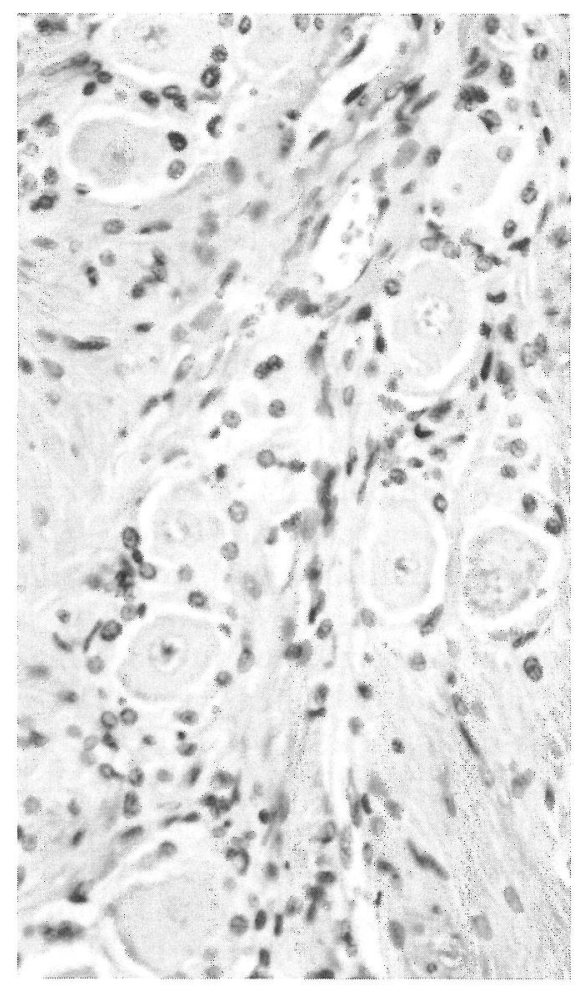

c

FIGS. 3a-c. Case 6. a. Positive signals were detected by in situ hybridization of the right trigeminal ganglion with a ${ }^{35} \mathrm{~S}-\mathrm{labeled}$ ICP0 sense probe. Hybridizations were located in the nuclei of ganglion cells. b, c. Slightly weaker signals were shown by in situ hybridization of the right geniculate ganglion with digoxigenin-labeled ICP0 sense probe (Fig. 3b); but no hybridization was detected with digoxigenin-labeled ICP0 antisense probe (Fig. 3c).

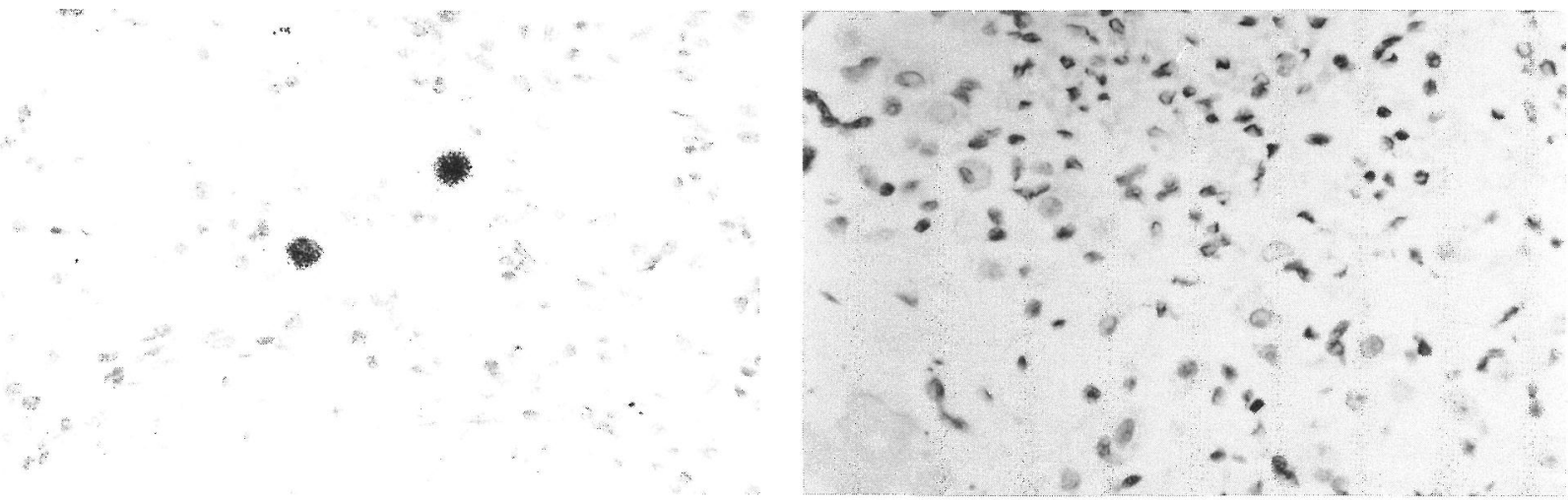

a

b

FIGs. 4a, b. In situ hybridization with digoxigenin-labeled ICP0 sense probe (case 7). Positive hybridization was observed in the right trigeminal ganglion (Fig. 4a); but no signal was present in the right spiral ganglion (Fig. 4b). 
similar to that found in trigeminal ganglia.

We also attempted to detect HSV in the human spiral ganglia of the cochlear system. Although an LAT signal was detected in the neurons of the trigeminal ganglia (positive controls) (Fig. 4a), no positive signals were obtained in the spiral ganglia (Fig. 4b). However, the presence of HSV in the spiral ganglia was suggested by the fact that, in 7 of the 10 samples, the viral genome was amplified by the PGR method (Fig. 5).

Since the trigeminal ganglia had been decalcified with 10\% EDTA before hybridization in the spiral ganglia, we also examined the effect of EDTA. A positive signal was detected after as long as 7 days of immersion in EDTA (Fig. 6). This finding indicates that decalcification had little effect on the ISH, and cannot account for the discrepancy between ISH and PGR.

\section{DISCUSSION}

We used ISH to detect the HSV genome in both productive and latent infections, and confirmed previous reports that ISH is a reliable method for detec-

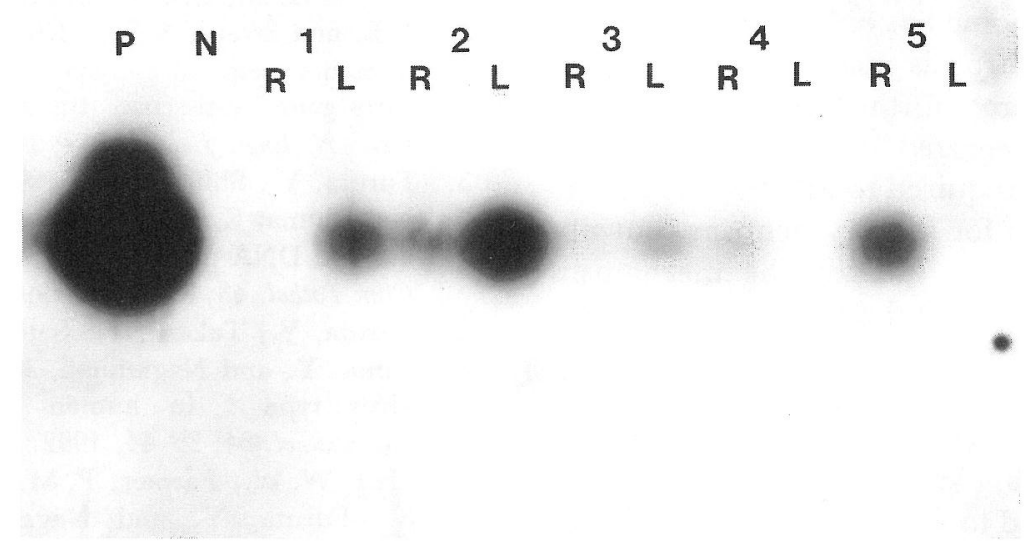

Fig. 5. Detection of HSV-1 DNA in the spiral ganglia by Southern blot hybridization with the HSV TK probe labeled by PCR. P, HSV-1 strain K192 DNA used as a positive control. N: ganglia from a newborn baby, 1-5: case numbers, R: the right ganglia, L: the left ganglia. HSV-1 DNA was detected in 7 of the 10 spiral ganglia from these 5 cases.

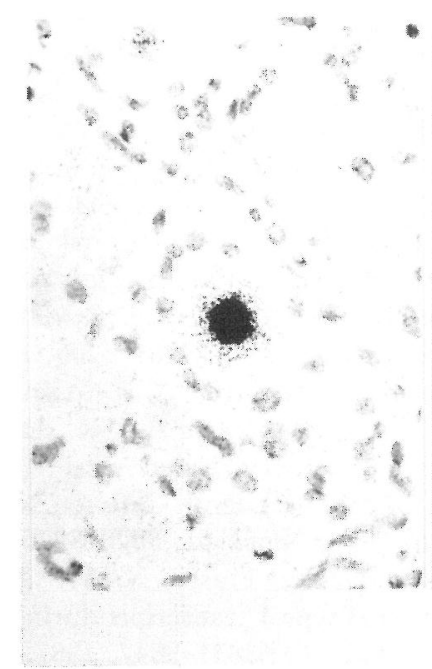

a

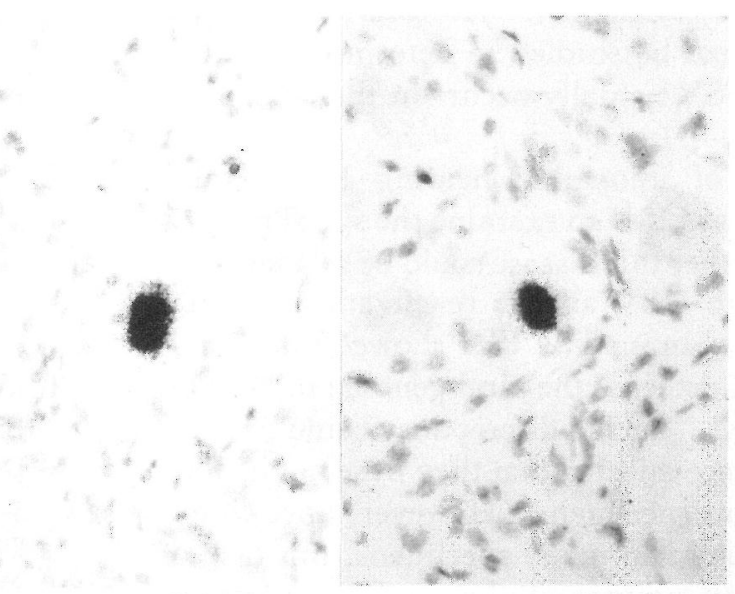

3 days

$\mathrm{b}$

\section{7 days}

c

FIGs. 6a-c. The intensity of in situ hybridization signals in the trigeminal ganglion was not diminished after treatment with $10 \%$ EDTA for 3 (Fig. 6b) to 7 (Fig. 6c) days compared with that in the untreated ganglion (Fig. 6a). 
ting latent virus infection $(2,4,7,11,12)$. In the latent form of viral infection, HSV cannot be visualized, even with an electron microscope, and its viral proteins cannot be labeled with any specific antibody. In fact, viral latency had only been suggested from the fact that the virus could be detected in cultured tissue. Nevertheless, the identity of the cells which harbor the virus has remained unknown. The present study demonstrates that ISH is the only available method that can localize latent viral infection.

The most common clinical manifestation of $\mathrm{HSV}$ is a recurrent vesicular eruption ("cold sore"), which appears most frequently at the mucocutaneous junctions around the lips or nostrils. Between attacks, this virus remains latent in the neurons of the trigeminal ganglia. The HSV genome has only been detected in neurons. Since the neuron is made up of developed cells that do not undergo further cell division, the HSV can be stably integrated in the DNA of these cells. Further study is required to identify the factors that direct viral tropism for sensory neurons, but not for motor neurons, and to identify the mechanism responsible for reactivation of the virus. Nonspecific stimuli, such as respiratory infection, fever, or sunlight, cause the virus to spread from the trigeminal ganglia via the sensory nerves to the areas of the skin supplied by these nerves. We are currently searching for factors that may bind to a viral promoter-enhancer to evoke the productive cycle of the virus.

It has been suggested that the reactivation of $\mathrm{HSV}$ in the geniculate ganglion may play a role in idiopathic peripheral facial nerve palsy (Bell's palsy) (13). ISH has established the latency of HSV in the human geniculate ganglia (4). However, more cases of facial palsy must be studied to determine whether reactivation of $\mathrm{HSV}$ actually occurs in the geniculate ganglia.

The cause of idiopathic hearing loss is also unknown. We used ISH to examine the spiral ganglia to determine whether this disease could be related to latent infection with HSV and its reactivation. While non of the cases examined by ISH showed infections, the PCR method detected the viral genome in 7 of the 10 cases examined. Such a discrepancy could occur if so few neurons were infected that they were not included in the ISH tissue specimens. However, since we examined many cases and many specimens, this lack of an ISH signal may indicate another, unknown form of HSV latency which may exist only between HSV and the neurons of the cochlear system.

\section{ACKNOWLEDGMENTS}

We are grateful to Dr. B. Roizman, Dr. K. Fujinaga, and Dr. H. Sakaoka for providing the plasmids in which HSV-1 DNA was cloned. We also thank Dr. $\mathrm{R}$. Hondo of the Institute of Public Health for the kind donation of DNA extracted from HSV-1 strain K192.

\section{REFERENCES}

1. Baringer, J. R. and Swoveland, P.: Recovery of herpessimplex virus from human trigeminal ganglion. N. Engl. J. Med. 288; 648-650, 1973.

2. Croen, K. D., Ostrove, J. M., Dragogic, L. J., Smialek, J. E. and Straus, S. E.: Latent herpes simplex virus in human trigeminal ganglia. Detection of an immediate early gene "anti-sense" transcript by in situ hybridization. N. Engl. J. Med. 317; 1427-1432, 1987.

3. Furuta, Y., Shinohara, T., Sano, K., Meguro, M. and Nagashima, K.: In situ hybridisation with digoxigeninlabelled DNA probes for detection of viral genomes. $J$. Clin. Pathol. 43; 806-809, 1990.

4. Furuta, Y., Takasu, T., Sato, K. C., Fukuda, S., Inuyama, Y. and Nagashima, K.: Latent herpes simplex virus type 1 in human geniculate ganglia. Acta Neuropathol. 84; 39-44, 1992.

5. Hall, W. W., Farmer, P. M., Takahashi, H., Tanaka, S., Furuta, Y. and Nagashima, K.: Pathological features of virus infections of the central nervous system (CNS) in the acquired immunodeficiency syndrome (AIDS). Acta Pathol. Jpn. 41; 172-181, 1991.

6. Lynas, C., Cook, S. D., Laycock, K. A., Bradfield, J. W. B. and Maitland, N. J.: Detection of latent virus mRNA in tissues using the polymerase chain reaction. $J$. Pathol. 157; 285-289, 1989.

7. McGeoch, D. J., Dalrymple, M. A., Davison, A. J., Dolan, A., Frame, M. C., McNab, D., Perry, L. J., Scott, J. E. and Taylor, P.: The complete DNA sequence of the long unique region in the genome of herpes simplex virus type 1. J. Gen. Virol. 69; 1531-1574, 1988.

8. Post, L. E., Conley, A. J., Mocarski, E. S. and Roizman, B.: Cloning of reiterated and nonreiterated herpes simplex virus 1 sequences as Bam HI fragments. Proc. Natl. Acad. Sci. USA 77; 4201-4205, 1980.

9. Rock, D. L., Nesburn, A. B., Ghiasi, H., Ong, J., Lewis, T. L., Lockensgard, J. R. and Wechsler, S. L.: Detection of latency-related viral RNAs in trigeminal ganglia of rabbits latently infected with herpes simplex virus type 1. J. Virol. 61; 3820-3926, 1987.

10. Spivack, J. G. and Fraser, N. W.: Detection of herpes simplex virus type 1 transcripts during latent infection in mice. J. Virol. 61; 3841-3847, 1987.

11. Stevens, J. G., Wagner, E. K., Devi-Rao, G. B., Cook, M. L. and Feldman, L. T.: RNA complementary to a herpesvirus $\alpha$ gene mRNA is prominent in latently infected neurons. Science 235; 1056-1059, 1987. 
12. Takasu, T., Furuta, Y., Sato, K. G., Fukuda, S., Inuyama, Y. and Nagashima, K.: Detection of latent herpes simplex virus DNA and RNA in human geniculate ganglia by the polymerase chain reaction. Acta
Otolaryngol. (Stockh) 112; 1004-1011, 1992.

13. Vahlne, A., Edström, S., Arstila, P., Beran, M., Ejnell, H., Nylen, O. and Lycke, E.: Bell's palsy and herpes simplex virus. Arch. Otolaryngol. 107; 79-81, 1981. 